\title{
Research on the Matching Between College Students' Employment Ability Training and Social Demand
}

\author{
ZHANG $\mathrm{Yi}^{1, \mathrm{a}}$ \\ ${ }^{1}$ Shandong Laber Vocational and Technical College, Ji'nan, Shandong, 250001 China \\ asnoopy89@163.com
}

Keywords: College students' employment ability; Social demand; Matching

\begin{abstract}
Full employment of college students represents an aspect of great concern in the harmonious social development, and their employment is largely a function of the match between their ability to obtain employment and the social demand. The findings of a survey of such a match show that they see a lower match with the demand in terms of ability of innovation, practice, social sense of responsibility and interpersonal relation. That is largely attributed to problems with the talent fostering mechanisms in colleges and universities. In addition, theory shortages are seen in human capital, resource-based view, academic capital and labor-job match. To enhance the match between the two above entails establishing a static and a dynamic mechanisms among such entities as colleges and universities, employers, governments and college students.
\end{abstract}

\section{Introduction}

The stage of the research on the employment ability is general in line with the social demand for job hunters, including an improved ability with wide significance in macroscopic terms, and the personal ability for employment in microscopic terms. An in-depth analysis of influencing factors of the ability and internal structure may extend theoretical and practical support for research on relevant problems. This paper, based on the survey of the match above, is aimed at figuring out the gaps between the two and the causes of the gaps, and raising relevant mechanism building strategies with the focus on such improved ability and the match.

\section{Analysis of Fostering of College Student's Ability}

\section{A. Ability obtained from extracurricular activities}

Over 60 percent of college students believe that they obtain and have improved employment ability by the involvement in such activities at school. Among others, independent living, communication, act and deal with matters and interpersonal exchange ability are among the ones to be obtained the easiest.

\section{B. Major contributors to the formation of college students' ability}

Such contributors primarily comprise college student themselves, instructors' competence, and school teaching mode and college climate. In addition, other minor factors include home education, general social trend and climate as well as the ideological guidance for the students by the instructors, etc. See Table 1.

Table 1 Major Contributors to Formation of College Students’ Employment Ability (unit: \%)

\begin{tabular}{|c|c|c|}
\hline & Yes & No \\
\hline College students & 63.9 & 36.1 \\
\hline Instructors' competence & 25.6 & 74.4 \\
\hline College teaching mode & 51.1 & 48.9 \\
\hline College climate & 53.2 & 46.8 \\
\hline
\end{tabular}


According to the statistics, the majority of students hold that the personal competence, campus growth environment and college teaching mode are among the contributors to the formation of their ability, shown in Table 2.

Table 2 Other Influencing Factors

\begin{tabular}{|c|c|c|}
\hline & Frequency & $\begin{array}{c}\text { Frequency } \\
/ \%\end{array}$ \\
\hline $\begin{array}{c}\text { College students, Instructors' competence, College } \\
\text { teaching mode and college climate }\end{array}$ & 128 & 96.2 \\
\hline Home education & 2 & 1.6 \\
\hline Social trend & 1 & 0.8 \\
\hline Social climate & 1 & 0.8 \\
\hline Poor ideological guidance of instructors to students & 1 & 0.8 \\
\hline Total & 133 & 100 \\
\hline
\end{tabular}

\section{Research and Analysis of the Match between College Students' Employment Ability Fostering and Social Demand}

\section{A. Employers prioritize college students' ability}

According to a survey, over 70 percent of employers attach great importance to college students' ability in communication, role transfer and professional ethic. Meanwhile, over $50 \%$ of the employers think highly of their ability to fix problems using their own acquired knowledge and self-study.

\section{B. Conflicts between college students' employment ability and social demand}

Social demand on college students' competence and ability is multiple. A survey shows that there is a marked disparity between their ability and the social demand. On one hand, competence varies from student to student. On the other hand, there is a great gap between the ability and the social demand, with the match in terms of innovation, practice and social sense of responsibility and interpersonal exchange is even less than 50 percent, and that of cultural quality, professional competence, organization and coordination ability and team work spirit as well as study ability only stands between 30 percent and 50 percent. Only that between the physical competence and the demand is less than $10 \%$. It indicates that college students' quality and competence far fail to cater to the demand.

\section{Quality analysis of assessment of college students' employment ability}

It is to analyze the internal confidence, i.e. internal consistency and split-half confidence. The analysis using SPSS software shows that the confidence of scale is Cronbach $a=0.8478$, very good (shown in Table 3)

Table 3 Internal Consistency of College Students’ Employment Ability Scale

\begin{tabular}{|l|c|c|c|c|}
\hline \multicolumn{1}{|c|}{ Item } & $\begin{array}{c}\text { Mean of } \\
\text { scale if this } \\
\text { item is } \\
\text { removed }\end{array}$ & $\begin{array}{c}\text { Variance of } \\
\text { scale if this } \\
\text { item is } \\
\text { removed } \\
\text { of this item } \\
\text { related to } \\
\text { the general } \\
\text { items }\end{array}$ & $\begin{array}{c}\text { a if this } \\
\text { item is } \\
\text { removed }\end{array}$ \\
\hline Confidence & 83.0817 & 37.5788 & 0.8027 & 0.8433 \\
\hline $\begin{array}{l}\text { Time management in an } \\
\text { efficient manner }\end{array}$ & 83.2903 & 39.4899 & 0.3654 & 0.8369 \\
\hline Listen to others & 83.3905 & 40.3463 & 0.3278 & 0.8379 \\
\hline $\begin{array}{l}\text { Assessment of organizational } \\
\text { need }\end{array}$ & 83.0870 & 37.5728 & 0.5519 & 0.8483 \\
\hline Development career & 83.4783 & 41.6765 & 0.1897 & 0.8422 \\
\hline Fix problem & 83.2791 & 39.7689 & 0.3789 & 0.8412 \\
\hline Operate and control & 83.1705 & 37.2430 & 0.5342 & 0.8178 \\
\hline
\end{tabular}




\begin{tabular}{|c|c|c|c|c|}
\hline $\begin{array}{l}\text { Tend to establish mutual trust } \\
\text { with others }\end{array}$ & 83.2763 & 39.4597 & 0.4332 & 0.8441 \\
\hline $\begin{array}{l}\text { Clearly express complicated } \\
\text { ideas }\end{array}$ & 83.1505 & 38.5332 & 0.6939 & 0.8376 \\
\hline $\begin{array}{l}\text { Ability to seek essence from } \\
\text { phenomena }\end{array}$ & 83.1789 & 38.4583 & 0.5589 & 0.8432 \\
\hline $\begin{array}{l}\text { Identify core factors to } \\
\text { successful business }\end{array}$ & 83.2409 & 39.4637 & 0.4532 & 0.8449 \\
\hline Interpersonal ability & 83.4348 & 41.4644 & 0.2655 & 0.8426 \\
\hline $\begin{array}{ll}\begin{array}{l}\text { Conduct } \\
\text { self-assessment }\end{array} & \text { proper } \\
\end{array}$ & 83.3913 & 40.3332 & 0.2786 & 0.8357 \\
\hline Chart a right career plan & 83.1870 & 37.2490 & 0.7994 & 0.8378 \\
\hline Properly know yourself & 83.1789 & 38.5372 & 0.5375 & 0.8386 \\
\hline Affect and consult with others & 83.2596 & 38.5769 & 0.4764 & 0.8316 \\
\hline $\begin{array}{l}\text { Keen to identify and seize } \\
\text { opportunities }\end{array}$ & 83.2609 & 39.6776 & 0.47665 & 0.8390 \\
\hline Think systematically & 83.3659 & 40.1987 & 0.3545 & 0.8395 \\
\hline $\begin{array}{l}\text { Think in an innovative } \\
\text { manner }\end{array}$ & 83.2496 & 39.5637 & 0.4988 & 0.8439 \\
\hline Stand pressure & 83.1923 & 38.4553 & 0.5674 & 0.8332 \\
\hline $\begin{array}{l}\text { Have strong self-management } \\
\text { ability }\end{array}$ & 83.2711 & 39.7536 & 0.4532 & 0.8387 \\
\hline $\begin{array}{l}\text { Qualify for quality } \\
\text { management }\end{array}$ & 83.2174 & 38.5536 & 0.4788 & 0.8405 \\
\hline Have strong learning ability & 83.2011 & 38.5768 & 0.5335 & 0.8356 \\
\hline Enjoy highly flexibility & 83.3684 & 40.5673 & 0.3457 & 0.8429 \\
\hline Proper oral exchange & 83.1933 & 38.5536 & 0.5332 & 0.8465 \\
\hline $\begin{array}{l}\text { Establish mutual-support with } \\
\text { others }\end{array}$ & 83.2669 & 38.6698 & 0.4576 & 0.8388 \\
\hline Focus on major issues & 83.2174 & 38.6298 & 0.5674 & 0.8378 \\
\hline $\begin{array}{l}\text { Equipped with specialized } \\
\text { technical knowledge }\end{array}$ & 83.4700 & 41.6736 & 0.2543 & 0.8433 \\
\hline $\begin{array}{l}\text { Honestly act and deal with } \\
\text { matters }\end{array}$ & 83.2609 & 39.2834 & 0.4876 & 0.8416 \\
\hline $\begin{array}{l}\text { Ability to transform vision } \\
\text { into concrete actions }\end{array}$ & 83.3801 & 40.9438 & 0.3389 & 0.8411 \\
\hline
\end{tabular}

Table 4 Classifications of Indicator system of College Students' Employment Ability

\begin{tabular}{|c|l|}
\hline Factor & \multicolumn{1}{|c|}{ Name of Indicator } \\
\hline Ability to seek a job & Ability to plan career, identify and seize opportunities, and develop career \\
\hline $\begin{array}{c}\text { Professional } \\
\text { competence }\end{array}$ & $\begin{array}{l}\text { Professional competence and ability to time management, identification, } \\
\text { practice and application, quality management, and act }\end{array}$ \\
\hline $\begin{array}{c}\text { Interpersonal } \\
\text { relationship }\end{array}$ & $\begin{array}{l}\text { Ability to expression, listening, affect others, interpersonal exchange, } \\
\text { communication, cooperation and win others' trust }\end{array}$ \\
\hline Self-development & Ability to problem solution, thinking, innovation and learning \\
\hline Emotion regulation & $\begin{array}{l}\text { Awareness of organization, integrity, flexibility, ability to face pressure, } \\
\text { self-management, self-knowing and self-assessment, and insight, } \\
\text { self-confidence and ability to focus on major issues }\end{array}$ \\
\hline
\end{tabular}


There is still some disparity between the theory construction and the reality of college students' employment ability. Four factors such as ability to time management, identification, quality management and act are included into the professional competence. The ability to seek a job is added with the ability to career development. Interpersonal relationship sees an additional ability to win other's rust. The self-development ability sees the added ability to think. Emotion regulation ability has no added factors.

\section{Analysis of causes of shortages of college students' employment ability}

Colleges and universities' talent fostering mechanisms limit the development of college students' employment ability. According to a survey, college teaching and fostering plan, learning procedure, content and examination mode are the four contributors to the low match between the students' ability and the demand. A combination of over a half time being devoted to the theory teaching and graduation project and the passive study in most cases, which are dominated by infusing, leads to an undesirable outcome. While the time to practical teaching and skill training represents some 30 percent of the total.

Table 5 Time Devotion of College Students (Unit: / \%)

\begin{tabular}{|c|c|c|c|c|c|c|c|}
\hline Item & Class & Self-study & $\begin{array}{c}\text { Entertainme } \\
\text { nt }\end{array}$ & Sports & $\begin{array}{c}\text { Social } \\
\text { practice }\end{array}$ & Exams & $\begin{array}{c}\text { Surf the } \\
\text { Internet }\end{array}$ \\
\hline $\begin{array}{c}\text { Frequenc } \\
\text { y }\end{array}$ & 45.3 & 18.6 & 12.3 & 1.1 & 2.3 & 5.1 & 15.3 \\
\hline
\end{tabular}

According to Table 5, college students devote extremely little time to social practice, while that to class, self-study, and exams makes up the vast majority. The vast majority of colleges and universities focus on the examination of acquired knowledge, which tends to lead in “exam-oriented" talents, as shown in Table 6.

Table 6 Overview of Examinations and Their Forms for College Student

\begin{tabular}{|c|c|c|c|c|c|c|}
\hline Item & \multicolumn{2}{|c|}{ Test of each course } & Scholarship & Diploma & $\begin{array}{c}\text { Degree } \\
\text { certificate }\end{array}$ \\
\hline Form & $\begin{array}{c}\text { Closed } \\
\text {-book }\end{array}$ & $\begin{array}{c}\text { Open- } \\
\text { book }\end{array}$ & $\begin{array}{c}\text { Minor } \\
\text { thesis }\end{array}$ & $\begin{array}{c}\text { Total scores, individual } \\
\text { discipline scores of all } \\
\text { course in each term and } \\
\text { attendance rate }\end{array}$ & $\begin{array}{c}\text { Total } \\
\text { credit }\end{array}$ & $\begin{array}{c}\text { Graduation } \\
\text { thesis and } \\
\text { thesis oral } \\
\text { defense }\end{array}$ \\
\hline
\end{tabular}

E. Analysis of match between the enhanced college students' ability and the social demand

Firstly, shift talent fostering mode. Take a holistic approach to the reform and innovation of both concept and methodology of college and university's teaching, so as to build a professional teaching system that contributes to an enhanced professional competence of college students. Adapt teaching concept and content to foster the talents that meet the social demand. Adjust professional configuration and fostering orientation by strengthening practical teaching related to the profession. That will significantly improve college students’ professional competence.

Secondly, have in place a rating system of individual college students. That means systematically rating the career, personality, professional competence, and desired job using the Internet so as to allow college students to have a whole picture of themselves and provide reference for them to determine their own development orientation. From time to time, allow college students to work out development goals and plans, and in this process, the responsible schools should well acquaint with the development trends of most of college students in microscopic terms, so as to strength and improve their teaching schemes.

Thirdly, strengthen practical training and enhance students' ability to fix problems. Such ability means the capacity for analyzing and solving problems. To that end, colleges and universities must provide students with opportunities and platform to get involved in practice as many as possible.

Fourthly, intensify employment guidance for better ability to seek jobs. Colleges and universities should intensify the reform and innovation of employment guidance, in an view to seek students' enhanced ability to seek jobs in an all-round way. A new type of employment guidance mode should cover the whole phase from freshman to senior. The guidance contents and forms should vary from phase to phase, so as to carry out career development educational programs. 
Fifthly, put education and guidance of employment outline on higher agenda so as to enhance college students' relative employment ability. Employment outline underpins college students' wishes, attitudes, goals, ideas and faith, etc for their career lives. And just due to the presence of the outline, they can make use of the information of concern to them and act in the manner that is in line with their outlines.

\section{Conclusions}

To enhance the match of the employment ability and the demand consists in building a matching mechanism. Such a mechanism should not only comply with the fundamental principle of "harmonious development" of college students' employment ability, but also cater to the needs of the match between the two. For that to happen, college and university, government, and college student, as major constituents, should establish an operational mechanism featuring interaction between static and dynamic match.

\section{References}

[1]Sun Jin, Chen Fuqiang. Research on the Matching Between College Students' Employment Ability and Social Demand [J]. China Adult Education, 2016,22:62-64.

[2]Tu Pinghong, Zhou Suqin. On Roles and Importance of Vocational Guidance in Promoting College Students’ Employment [J]. Journal of Yichun College,2017,02:121-124.

[3]Yang Na. Research on the Matching between Employment Ability and Social Demand for Marketing Majors [J]. Heilongjiang Education (Higher Education Research and Assessment), 2017,10:77-79.

[4] Cao Hongjun. On Supply-side reform of College Students’ Employment [J]. Academic Forum, 2016,05:159-163.

[5]Ma Yongxia, Liang Jinhui. Assessment and Research on Employment Ability of Science and Technology Majors [J]. Research On Education,2016,09:40-50. 